\title{
Model Penjadwalan Pemeliharaan Preventif Mesin-Mesin Produksi untuk Meminimasi Total Tardiness
}

\author{
Eri Wirdianto ${ }^{1 *}$, Irfan Nugraha Putra Mukhti ${ }^{1}$, Alexie Herryandie Bronto Adi ${ }^{1}$ dan Milana ${ }^{2}$ \\ ${ }^{1}$ Jurusan Teknik Industri, Fakultas Teknik, Universitas Andalas \\ Jurusan Teknik Otomotif, Fakultas Teknik, Universitas Negeri Padang \\ "Corresponding author, e-mail: eri_wirdianto@eng.unand.ac.id
}

\begin{abstract}
Abstrak - Pemeliharaan preventif merupakan sebuah metode untuk menghindari kerusakan tak terduga pada mesin-mesin produksi. Namun, pelaksanaan pemeliharaan tersebut dibatasi oleh ketersediaan sumber daya sehingga dapat menyebabkan keterlambatan. Penelitian ini bertujuan untuk meminimalkan keterlambatan total pada pemeliharaan preventif mesin-mesin produksi dengan mengembangkan model penjadwalan. Model penjadwalan ini mempertimbangkan ketersediaan waktu dan teknisi. Model ini dikembangkan dengan menggunakan pendekatan Integer Linear Programming. Model ini menghasilkan keluaran dalam bentuk jadwal pemeliharaan preventif melalui fungsi tujuan yang mempertimbangkan kendala yang diidentifikasi pada perusahaan. Model penjadwalan yang dikembangkan ini mampu memberikan usulan atas jadwal pemeliharaan preventif yang dapat meminimalkan waktu keterlambatan total.
\end{abstract}

Kata Kunci: Integer Linear Programming, Keterlambatan, Pemeliharaan Preventif, Penjadwalan

\begin{abstract}
Preventive maintenance is considered as a method to avoid unexpected failure on production machines. Unfortunately, conducting such maintenance is limited by resources availability thus likely causes tardiness. This research aims to minimize total tardiness of preventive maintenance on production machines by developing a scheduling model. This model considers the availability of time and technician to get an optimal schedule. The model of preventive maintenance scheduling is developed by using the Integer Linear Programming approach. The output is in the form of preventive maintenance schedule through an objective function which considers the specified constraints. The developed model can provide a preventive maintenance schedule which minimize the total tardiness.
\end{abstract}

Keywords: Integer Linear Programming, Tardiness, Preventive Maintenance, Scheduling

This is an open access article distributed under the Creative Commons 4.0 Attribution License

\section{Pendahuluan}

Kerusakan mesin dalam proses produksi merupakan faktor yang sangat tidak diharapkan untuk terjadi. Jika mesin mengalami kerusakan pada saat kegiatan produksi berlangsung, maka target produksi akan terganggu, yang akan mempengaruhi jumlah produk yang mampu dihasilkan dan pada akhirnya menyebabkan keterlambatan pengiriman produk. Kerugian lainnya, biaya yang harus dikeluarkan perusahaan untuk perbaikan mesin menjadi beban yang tidak terhindarkan [1]. Oleh karena itu, usaha untuk menghindari atau meminimalkan kemungkinan terjadinya kerusakan mesin ketika produksi berlangsung sangat penting untuk dilakukan.

Frekuensi kerusakan mesin dapat dikurangi dengan melakukan usaha pencegahan berupa pemeliharaan preventif (preventive maintenance). Pemeliharaan preventif adalah pemeliharaan yang dilakukan dengan interval waktu dimana inspeksi berkala dilakukan pada mesin untuk mengetahui peningkatan pemakaian pada komponen dan subsistemnya [2]. Aktivitas pemeliharaan preventif biasanya berupa pemeriksaan terhadap berbagai komponen secara periodik untuk mengetahui apakah pengaturan dan penggantian sudah diperlukan $[3,4]$. 
Tujuan dasar pemeliharaan preventif adalah melakukan kegiatan pemeliharaan yang terencana untuk meningkatkan kehandalan mesin sehingga dapat meminimalkan dan menghindari kerusakan [5]. Elemen dasarnya mencakup inspeksi, kalibrasi, pengujian, penyesuaian, servis, instalasi, dan penjajaran (alignment) [6,7]. Dengan pemeliharaan preventif ini mesin dapat dipertahankan untuk berada dalam kondisi yang diharapkan. Pemeriksaan dan perbaikan dilakukan di saat awal terjadinya penurunan performa mesin [8].

Metode yang sering digunakan untuk menentukan jadwal pemeliharaan preventif adalah Reliability Based Maintenance. Metode ini bertujuan untuk membuat interval pemeliharaan baru pada mesin sehingga jadwal selanjutnya dibuat berdasarkan interval pemeliharaan tersebut. Data yang digunakan untuk metode ini adalah data kerusakan yang terjadi pada mesin. Namun, tidak semua perusahaan melakukan pendataan kerusakan dengan baik sehingga data kerusakan pada perusahaan seringkali belum memadai untuk digunakan.

Metode yang mampu dan dipilih untuk melakukan penjadwalan adalah Integer (zero-one) Linear Programming (ILP). Contoh penggunaan metode ini adalah untuk penjadwalan hidup/mati (on/off) mesin-mesin Raw Mill dan Cement Mill [9]. Selain penjadwalan operasi, metode ILP juga telah digunakan untuk menjadwalkan produksi untuk meminimasi keterlambatan pemenuhan pesanan [10]. Berdasarkan penjelasan tersebut dapat disimpulkan bahwa metode ILP dapat digunakan untuk melakukan penjadwalan pemeliharaan yang meminimasi keterlambatan dari target waktu pelaksanaan.

\section{METODE}

\section{A. Pemilihan Metode}

Aktivitas pemeliharaan preventif yang dilakukan perusahaan umumnya melibatkan banyak mesin dan jenis aktivitas, namun dengan sumber daya yang terbatas. Akibatnya pemeliharaan preventif yang dilakukan perusahaan sering mengalami keterlambatan. Keterlambatan pemeliharaan dapat menyebabkan lebih cepatnya penurunan performa mesin yang dapat mengakibatkan terjadinya kerusakan ketika proses produksi berlangsung. Penyebabnya adalah kurangnya perencanaan dalam menjadwalkan aktivitas pemeliharaan. Dengan demikian, perlu dilakukan penjadwalan pemeliharaan preventif yang optimal agar keterlambatan dapat diminimasi.

Pengembangan model penjadwalan dengan pendekatan binary integer programming, yang merupakan bentuk khusus dari ILP, mampu memberikan jadwal pelaksanaan kegiatan pemeliharaan preventif bagi mesin-mesin produksi dengan mempertimbangkan berbagai batasan sehingga keterlambatan pelaksanaan kegiatan pemeliharaan dapat diminimasi. Implementasi dari hasil penelitian ini diharapkan mampu meningkatkan keandalan (reliability) dari mesinmesin yang digunakan.

Validasi terhadap model penjadwalan pemeliharaan preventif ini dilakukan di PT Jaya Sentrikon Indonesia (PT JSI).

\section{B. Formulasi Model}

Pembuatan jadwal pemeliharaan preventif pada PT JSI dapat diselesaikan dengan menggunakan metode Integer Linear Programming. Sistem penjadwalan pemeliharaan preventif yang telah ada diformulasikan menjadi model matematis. Tahapan formulasi model matematis tersebut terdiri dari :

a. Tahapan Pendeskripsian Sistem

Tahap ini dilakukan untuk mengetahui sistem nyata dari sistem pemeliharaan preventif pada PT JSI. Sistem nyata digambarkan dalam influence diagram untuk memperjelas permasalahan yang terjadi pada sistem.

b. Tahapan Pemodelan Matematis

Tahapan ini terdiri dari :

- Mendeskripsikan permasalahan ke dalam bentuk matematis yakni dengan menentukan variabel keputusan, fungsi kendala, dan menentukan fungsi tujuan.

- Verifikasi dan validasi model

Verifikasi model dilakukan dengan uji dimensi dan inspeksi model. Verifikasi bertujuan untuk memeriksa kesesuaian logika model dan kesesuaian data. Validasi model dilakukan dengan validitas konstruk. Validasi bertujuan untuk mengetahui apakah model sudah mewakili sistem nyata dan mampu menyelesaikan permasalahan pada perusahaan.

c. Analisis

Formulasi model menghasilkan model penjadwalan yang mampu meminimasi keterlambatan pemeliharaan preventif mesinmesin produksi di PT JSI, yang selanjutnya dilakukan analisis berupa analisis model dan analisis sensitivitas. 


\section{HASIL DAN ANALISA}

\section{A. Formulasi Permasalahan}

Beberapa hal yang perlu diperhatikan dalam pemeliharaan preventif di PT JSI yakni penjadwalan pemeliharaan preventif, waktu pemeliharaan preventif, pemeliharaan preventif dilakukan ketika hari Minggu, tenaga kerja/staf, interval pemeliharaan preventif mesin, dan lama waktu pemeliharaan preventif pada mesin. Permasalahan pada sistem digambarkan dalam influence diagram yang dibuat berdasarkan elemen-elemen yang ada dalam sistem. Struktur sistem terdiri dari input (controllable dan uncontrollable), komponen (terbentuk dari hubungan beberapa input), dan output (keluaran yang diinginkan). Identifikasi elemen-elemen sistem pemeliharaan preventif mesin-mesin produksi di PT JSI dapat dilihat pada Tabel 1. Keterkaitan antara elemen input, komponen dan output disajikan dalam bentuk influence diagram sistem pemeliharaan preventif mesin-mesin produksi di PT JSI seperti ditampilkan pada pada Gambar 1.

Tabel 1. Elemen-elemen sistem pemeliharaan preventif mesin-mesin produksi di PT JSI

\begin{tabular}{|c|l|c|}
\hline No & \multicolumn{1}{|c|}{ Aspek atau Item } & Identifikasi \\
\hline 1 & Jam Jalan Mesin di Awal Perencanaan & input (uncontrollable) \\
2 & Jam Kerja Mesin per Hari & input (controllable) \\
3 & Jumlah Hari Kerja per Minggu & input (controllable) \\
4 & Jumput (controllable) \\
5 & Ketentuan Minggu per Tahun & input (controllable) \\
6 & Jam Kerja Tersedia untuk Pemeliharaan Preventif & input (controllable) \\
7 & Jumlah Tenaga Kerja Tersedia & input (controllable) \\
8 & Jam Kerja yang Dibutuhkan untuk Pemeliharaan Preventif & input (controllable) \\
9 & Jumlah Tenaga Kerja yang Dibutuhkan untuk Pemeliharaan Preventif & input (controllable) \\
10 & Waktu Jalan Mesin per Minggu & komponen \\
11 & Interval Pemeliharaan Mesin & komponen \\
12 & Jam Orang yang Dibutuhkan untuk Pemeliharaan Preventif & komponen \\
13 & Minimasi Waktu Keterlambatan Pemeliharaan Preventif Mesin & output \\
\hline
\end{tabular}

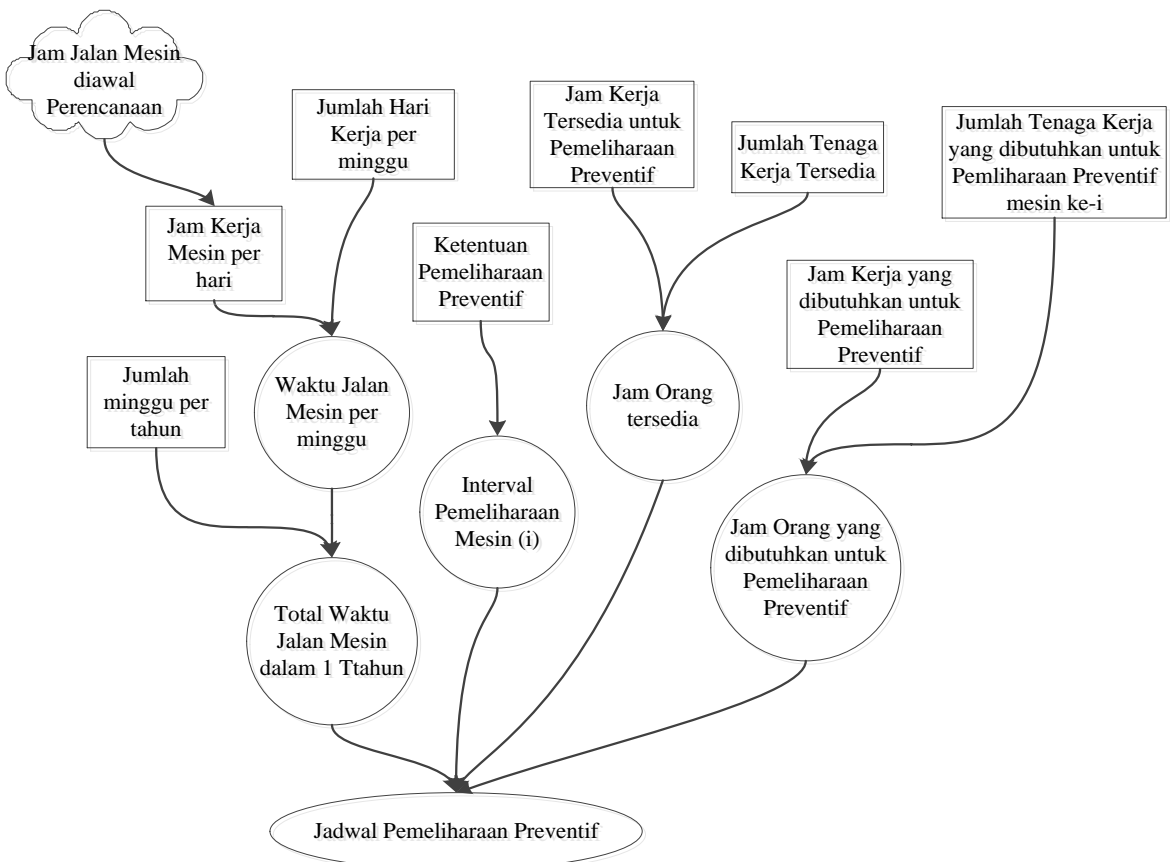

Gambar 1. Influence Diagram Sistem Pemeliharaan Preventif Mesin-mesin Produksi di PT JSI

\section{B. Formulasi Model Matematis}

Berdasarkan influence diagram yang telah dirancang, maka dapat diformulasikan model matematis untuk menggambarkan karakteristik sistem tersebut. Formulasi model berdasarkan pendekatan Integer Linear Programming. 


\section{Asumsi dan Parameter Model}

Asumsi yang digunakan dalam pembuatan model penjadwalan pemeliharaan preventif mesinmesin produksi di PT JSI adalah: jam kerja mesin per hari, jumlah hari kerja per minggu, dan lama waktu pemeliharaan setiap mesin adalah tetap. Parameter yang digunakan pada model penjadwalan pemeliharaan preventif mesin-mesin produksi dapat dilihat pada Tabel 2 .

Tabel 2. Parameter Model, Notasi dan Satuan

\begin{tabular}{|c|l|l|l|}
\hline No & Parameter Model & Notasi & Satuan \\
\hline 1 & Jam Jalan Mesin ke- $i$ sampai Perencanaan Dilakukan & $J i 00$ & Jam \\
2 & Jam Kerja Mesin Per Hari & $J k m$ & Jam \\
3 & Jumlah Hari Kerja Per Minggu & $J h m$ & Hari \\
4 & Jumlah Minggu Per Tahun & $J m t$ & Hari \\
5 & Tenaga Kerja Tersedia & $T k$ & Orang \\
6 & Jumlah Tenaga Kerja yang Dibutuhkan untuk Pemeliharaan & $T k i$ & Orang \\
7 & Preventif Mesin ke- $i$ & $J k h m$ & Jam \\
8 & Jam Kerja Pemeliharaan Preventif pada Hari Minggu & $J h k$ & Hari \\
9 & Lama Waktu Pemeliharaan Preventif Mesin ke- $i$ & $L p i$ & Jam \\
10 & Interval Pemeliharaan Mesin ke- $i$ & $I p i$ & Jam \\
11 & Jam Jalan Mesin ke- $i$ & $J m i$ & Jam \\
12 & Total Waktu Jalan Mesin ke- $i$ dalam 1 Tahun & $W i$ & Jam \\
13 & Waktu Keterlambatan Pemeliharaan Preventif Mesin & $Z$ & Jam \\
\hline
\end{tabular}

\section{Formulasi Model}

Formulasi model penjadwalan pemeliharaan preventif mesin-mesin produksi di PT JSI dibuat berdasarkan pendekatan ILP yang terdiri dari beberapa elemen yakni:

\section{Penetapan variabel keputusan}

$X_{i j}=$ Keputusan pelaksanaan pemeliharaan preventif pada mesin $i$ di minggu ke- $j$

$X_{i j}=1$, Jika dilakukan pemeliharaan pada mesin $i$ di minggu ke- $j$

$=0$, Jika tidak

Indeks $i$ menunjukkan nomor mesin dan indeks $j$ menunjukkan minggu. Indeks $i$ dan $j$ menggunakan angka dua digit untuk mencegah terjadinya kesalahan dalam formulasi. Contoh penggunaan indeksnya yakni pada mesin 1 dan minggu ke- 1 maka ditulis $\mathrm{X}_{0101}$.

\section{Penetapan fungsi kendala}

Pada model penjadwalan pemeliharaan preventif mesin-mesin produksi dirumuskan beberapa kendala sebagai berikut:

a. Jam kerja orang yang dibutuhkan untuk pemeliharaan preventif pada mesin tidak boleh melebihi jam kerja orang yang tersedia pada hari tersebut. Jam kerja orang didapatkan dari perkalian lama waktu pemeliharaan preventif dengan jumlah tenaga kerja yang dibutuhkan untuk mesin tersebut. Jumlah tenaga kerja yang tersedia pada hari minggu adalah 5 orang selama 8 jam kerja. Berikut persamaan untuk mendapatkan jam kerja orang.

$$
\sum_{\mathrm{i}=1}^{34}\left(L p_{i} \mathrm{x} T k_{i}\right) \mathrm{X}_{\mathrm{ij}} \leq \mathrm{Jkhm} \times \mathrm{Tk} \text { untuk setiap } j
$$

Setiap mesin memiliki jam kerja orang yang berbeda-beda. Hal ini dikarenakan waktu pemeliharaan preventif dan jumlah tenaga kerja yang dibutuhkan untuk melakukan pemeliharaan preventif yang berbeda pada setiap mesin. Jam kerja orang pada setiap mesin dapat dilihat pada Tabel 3.

Berdasarkan Tabel 3 diketahui bahwa beberapa mesin memiliki jam kerja orang yang sama. Contoh formulasi nilai jam kerja orang pada suatu mesin dapat dilihat pada persamaan berikut.

$\begin{aligned} 3 X_{0101}+3 X_{0201}+3 X_{0301} \ldots+1 X_{3401} & \leq 40 \\ 3 X_{0102}+3 X_{0202}+3 X_{0302} \ldots+1 X_{3402} & \leq 40 \\ \ldots+\ldots+\quad \ldots & \leq 40 \\ 3 X_{0152}+3 X_{0252}+3 X_{0352} \ldots+1 X_{3452} & \leq 40\end{aligned}$

b. Jumlah pemeliharaan preventif yang akan dilakukan pada mesin dalam satu tahun tidak boleh melebihi target yang ditetapkan. Target pemeliharaan preventif mesin dalam 1 tahun didapatkan dari perkalian jumlah hari kerja dalam setahun dengan jam kerja mesin per hari lalu dibagi interval pemeliharaan mesin yang dibulatkan ke bawah. Maka didapatkan persamaan sebagai berikut. 


\begin{tabular}{|c|c|}
\hline $\begin{array}{c}\text { No. } \\
\text { Mesin }\end{array}$ & $\begin{array}{c}\text { Jam } \\
\text { Kerja } \\
\text { Orang }\end{array}$ \\
\hline 1 & 3 \\
2 & 3 \\
3 & 3 \\
4 & 5 \\
5 & 5 \\
6 & 5 \\
7 & 5 \\
8 & 5 \\
9 & 18 \\
\hline
\end{tabular}

Tabel 3. Jam Kerja Orang untuk Setiap Mesin

\begin{tabular}{|c|c|}
\hline $\begin{array}{c}\text { No. } \\
\text { Mesin }\end{array}$ & $\begin{array}{c}\text { Jam } \\
\text { Kerja } \\
\text { Orang }\end{array}$ \\
\hline 10 & 18 \\
11 & 5 \\
12 & 5 \\
13 & 1 \\
14 & 1 \\
15 & 1 \\
16 & 1 \\
17 & 0.5 \\
18 & 0.5 \\
\hline
\end{tabular}

\begin{tabular}{|c|c|}
\hline $\begin{array}{c}\text { No. } \\
\text { Mesin }\end{array}$ & $\begin{array}{c}\text { Jam } \\
\text { Kerja } \\
\text { Orang }\end{array}$ \\
\hline 19 & 1 \\
20 & 1 \\
21 & 1 \\
22 & 1 \\
23 & 9 \\
24 & 9 \\
25 & 9 \\
26 & 9 \\
27 & 9 \\
\hline
\end{tabular}

\begin{tabular}{|c|c|}
\hline $\begin{array}{c}\text { No. } \\
\text { Mesin }\end{array}$ & $\begin{array}{c}\text { Jam } \\
\text { Kerja } \\
\text { Orang }\end{array}$ \\
\hline 28 & 9 \\
29 & 9 \\
30 & 9 \\
31 & 9 \\
32 & 9 \\
33 & 1 \\
34 & 1 \\
& \\
\hline
\end{tabular}

$\sum_{\mathrm{j}=1}^{52} \mathrm{X}_{\mathrm{ij}} \leq \operatorname{Int}\left(\left(J_{i 00}+\mathrm{Jhk} \times \mathrm{Jkm}\right) \div \mathrm{Ip}_{\mathrm{i}}\right) \quad$ untuk masingmasing $i$

sampai jadwal perencanaan dibuat. Jam jalan awal pada mesin-mesin di PT JSI disajikan dalam Tabel 4.

Jam jalan awal mesin $\left(J_{i 00}\right)$ adalah jam jalan mesin sejak pemeliharaan terakhir dilakukan perusahaan

Tabel 4. Jam Jalan Awal Mesin di PT JSI

\begin{tabular}{|l|l|l|l|l|}
\hline No & $\begin{array}{l}\text { Nomor } \\
\text { Identitas }\end{array}$ & $\begin{array}{l}\text { Jam } \\
\text { Jalan } \\
\text { Awal } \\
\text { Mesin }\end{array}$ & $\begin{array}{l}\text { Target } \\
\text { Pemeli- } \\
\text { haraan }\end{array}$ & $\begin{array}{l}\text { Total } \\
\text { Jam } \\
\text { Jalan } \\
\text { Mesin }\end{array}$ \\
\hline 1 & 01/MF/MSP & 360 & 9 & 4728 \\
2 & 02/MF/MSP & 360 & 9 & 4728 \\
3 & 03/MF/MSP & 360 & 9 & 4728 \\
4 & 01/SPN/MSP & 360 & 9 & 4728 \\
5 & 02/SPN/MSP & 360 & 9 & 4728 \\
6 & 03/SPN/MSP & 360 & 9 & 4728 \\
7 & 04/SPN/MSP & 360 & 9 & 4728 \\
8 & 05/SPN/MSP & 360 & 9 & 4728 \\
9 & 01/BL/MSP & 120 & 8 & 4488 \\
10 & 02/BL/MSP & 120 & 8 & 4488 \\
11 & 02/BP/RMC & 480 & 9 & 4848 \\
12 & 04/BP/RMC & 480 & 9 & 4848 \\
13 & 01/TO/MSP & 480 & 9 & 4848 \\
14 & 02/TO/MSP & 480 & 9 & 4848 \\
15 & 01/TP/MSP & 480 & 9 & 4848 \\
16 & 02/TP/MSP & 480 & 9 & 4848 \\
17 & 01/CC/MSP & 120 & 8 & 4488 \\
\hline
\end{tabular}

\begin{tabular}{|l|l|l|l|l|}
\hline No & $\begin{array}{l}\text { Nomor } \\
\text { Identitas }\end{array}$ & $\begin{array}{l}\text { Jam } \\
\text { Jalan } \\
\text { Awal } \\
\text { Mesin }\end{array}$ & $\begin{array}{l}\text { Target } \\
\text { Pemeli- } \\
\text { haraan }\end{array}$ & $\begin{array}{l}\text { Total } \\
\text { Jam } \\
\text { Jalan } \\
\text { Mesin }\end{array}$ \\
\hline 18 & 02/CC/MSP & 120 & 8 & 4488 \\
19 & $01 /$ TJ/MSP & 360 & 9 & 4728 \\
20 & 02/TJ/MSP & 360 & 9 & 4728 \\
21 & 03/TJ/MSP & 360 & 9 & 4728 \\
22 & 04/TJ/MSP & 360 & 9 & 4728 \\
23 & 01/OHC/MSP & 600 & 4 & 4968 \\
24 & 02/OHC/MSP & 600 & 4 & 4968 \\
25 & 03/OHC/MSP & 600 & 4 & 4968 \\
26 & 04/OHC/MSP & 600 & 4 & 4968 \\
27 & 05/OHC/MSP & 600 & 4 & 4968 \\
28 & 06/OHC/MSP & 720 & 4 & 5088 \\
29 & 07/OHC/MSP & 720 & 4 & 5088 \\
30 & 08/OHC/MSP & 720 & 4 & 5088 \\
31 & 09/OHC/MSP & 720 & 4 & 5088 \\
32 & 10/OHC/MSP & 720 & 4 & 5088 \\
33 & 01/MC/MSP & 480 & 4 & 4848 \\
34 & 02/MC/MSP & 480 & 4 & 4848 \\
\hline \multicolumn{5}{|l|}{} \\
\hline
\end{tabular}

Berdasarkan Tabel 4 diketahui bahwa setiap mesin memiliki jam jalan awal yang berbeda-beda dikarenakan pemeliharaan preventif sebelumnya. Berikut contoh perhitungan untuk target pemeliharaan preventif mesin untuk 52 minggu ke depan.

1. Target pemeliharaan preventif mesin ke 1 (interval $500 \mathrm{jam})$ :

$$
\begin{aligned}
& \operatorname{int}\left(\left(\mathrm{j}_{\mathrm{i} 00}+((365 \text { hari }-52 \text { hari }) \times 14)\right): 500\right) \\
& =\operatorname{int}((360+(313 \times 14)): 500) \\
& =\operatorname{int}(4728: 500) \\
& =9
\end{aligned}
$$

Berdasarkan perhitungan di atas diketahui bahwa target pemeliharaan preventif mesin 1 adalah 9 kali. Berikut adalah persamaan untuk mesin ke 1:

$$
\begin{aligned}
& \mathrm{X}_{0101}+\mathrm{X}_{0102}+\mathrm{X}_{0103} \ldots+\mathrm{X}_{0152} \leq 9 \\
& \mathrm{X}_{0201}+\mathrm{X}_{0202}+\mathrm{X}_{0203} \ldots+\mathrm{X}_{0252} \leq 9 \\
& \ldots+\ldots+\ldots+\ldots+\mathrm{X}_{2252} \leq 9 \\
& \mathrm{X}_{2201}+\mathrm{X}_{2202}+\mathrm{X}_{2203} \ldots+\mathrm{X}_{2252} \leq 9
\end{aligned}
$$

2. Target pemeliharaan preventif mesin ke 23 (interval $1000 \mathrm{jam})$

$$
\begin{aligned}
& \operatorname{int}\left(\left(\mathrm{j}_{\mathrm{i} 00}+((365 \text { hari }-52 \text { hari }) \times 14)\right): 1000\right) \\
& =\operatorname{int}((360+(313 \times 14)): 1000) \\
& =\operatorname{int}(4963: 1000) \\
& =4
\end{aligned}
$$

Berdasarkan perhitungan di atas diketahui bahwa target pemeliharaan preventif mesin 1 adalah 4 kali. Berikut adalah persamaan untuk mesin 23 .

$\mathrm{X}_{2301}+\mathrm{X}_{2302}+\mathrm{X}_{2303} \ldots+\mathrm{X}_{2352} \leq 4$
$\mathrm{X}_{2401}+\mathrm{X}_{2402}+\mathrm{X}_{2403} \ldots+\mathrm{X}_{2452} \leq 4$
$\ldots+\ldots+\ldots \quad \leq 4$
$\mathrm{X}_{3401}+\mathrm{X}_{3402}+\mathrm{X}_{3403} \ldots+\mathrm{X}_{3452} \leq 4$ 
c. Pemeliharaan preventif dilakukan ketika waktu jalan mesin telah melebihi interval waktu pemeliharaannya. Pada mesin dengan interval 500 jam pemeliharaan preventif dilakukan dengan jarak minimal 6 minggu. Hal ini karena jam kerja dalam 6 minggu adalah 504 jam, yang berarti telah memenuhi ketentuan di atas. Maka didapatkan persamaan umum sebagai berikut:

$\sum_{j=1}^{k_{1}} X_{i j} \leq 0$

$\sum_{j=1}^{k_{2}} X_{i j} \leq 1$

$\sum_{j=l}^{l+5} X_{i j} \leq 1$ untuk interval $500,1=1, \ldots, 47$

$\sum_{j=l}^{l+11} X_{i j} \leq 1$ untuk interval $1000,1=1, \ldots, 41$

$\sum_{j=l}^{l+6} X_{i j} \leq 2$ untuk interval $500,1=k_{2}, k_{2}+1, \ldots, 4$ (10)

$\sum_{j=l}^{l+12} X_{i j} \leq 2$ untuk interval $1000,1=k_{2}, k_{2}+1, \ldots, 40$

Nilai $k_{1}$ didapatkan dari pengurangan interval dengan jam jalan awal mesin dibagi dengan perkalian antar jam kerja mesin per hari dengan jumlah hari kerja per minggu lalu di rounddown. Begitu pula dengan nilai $k_{2}$, bedanya pada $k_{2}$ dilakukan roundup. Nilai $k_{1}$ berfungsi untuk menunjukkan minggu terakhir sebelum pemeliharaan preventif dilakukan. Nilai $k_{2}$ menunjukkan minggu terakhir dimana pemeliharaan preventif sudah bisa dilakukan. Berdasarkan penjelasan di atas maka didapatkan persamaan sebagai berikut:

$k_{1}=$ rounddown $\left(\frac{I p_{i-J_{i 00}}}{j k m * j h m}\right)$

$k_{2}=\operatorname{roundup}\left(\frac{I p_{i-J_{i 00}}}{j k m * j h m}\right)$

Diketahui bahwa jam kerja mesin per hari $(j \mathrm{~km})$ adalah 14 jam dan jumlah hari kerja per minggu $(\mathrm{jhm})$ adalah 6 hari. Berdasarkan persamaan yang telah didapatkan maka contoh perhitungan untuk mesin ke 1 adalah:

$k_{1}=$ rounddown $\left(\frac{500-360}{14 * 6}\right)=1$

$k_{2}=\operatorname{roundup}\left(\frac{500-360}{14 * 6}\right)=2$

Maka sebagai contoh didapatkan persamaan untuk mesin 1 sebagai berikut:

$\mathrm{X}_{0101} \leq 0$

$\mathrm{X}_{0101}+\mathrm{X}_{0102} \leq 1$

$\mathrm{X}_{0101}+\mathrm{X}_{0102}+\mathrm{X}_{0103} \ldots+\mathrm{X}_{0106} \leq 1$

$\mathrm{X}_{0102}+\mathrm{X}_{0103}+\mathrm{X}_{0104} \ldots+\mathrm{X}_{0107} \leq 1$

$\mathrm{X}_{0102}+\mathrm{X}_{0103}+\mathrm{X}_{0104 \ldots} \ldots+\mathrm{X}_{0108} \leq 2$

$\mathrm{X}_{0103}+\mathrm{X}_{0104}+\mathrm{X}_{0105} \ldots+\mathrm{X}_{0108} \leq 1$

$\mathrm{X}_{0103}+\mathrm{X}_{0104}+\mathrm{X}_{0105} \ldots+\mathrm{X}_{0109} \leq 2$

$\ldots+\ldots+\ldots \leq 1$

$\ldots+\ldots+\ldots \leq 2$

$\mathrm{X}_{0146}+\mathrm{X}_{0147}+\mathrm{X}_{0148 \ldots} \ldots+\mathrm{X}_{0151} \leq 1$

$\mathrm{X}_{0146}+\mathrm{X}_{0147}+\mathrm{X}_{0148 \ldots} \ldots+\mathrm{X}_{0152} \leq 2$

$\mathrm{X}_{0147}+\mathrm{X}_{0148}+\mathrm{X}_{0149 \ldots} \ldots+\mathrm{X}_{0152} \leq 1$

Dengan cara yang sama, untuk mesin dengan interval 1000 jam pemeliharaan preventif dilakukan dengan jarak minimal 12 minggu.
Hal ini karena jam kerja dalam 12 minggu adalah 1008 jam. Sebagai contoh untuk mesin ke 23 ,

$k_{1}=$ rounddown $\left(\frac{1000-600}{14 * 6}\right)=4$

$k_{2}=\operatorname{roundup}\left(\frac{1000-600}{14 * 6}\right)=5$

sehingga persamaan untuk mesin ke 23 adalah sebagai berikut:

$\mathrm{X}_{2301}+\mathrm{X}_{2302}+\mathrm{X}_{2303}+\mathrm{X}_{2304} \leq 0$

$\mathrm{X}_{2301}+\mathrm{X}_{2302}+\mathrm{X}_{2303}+\mathrm{X}_{2304}+\mathrm{X}_{2305} \leq 1$

$\mathrm{X}_{2301}+\mathrm{X}_{2302}+\mathrm{X}_{2303} \ldots+\mathrm{X}_{2312} \leq 1$

$\mathrm{X}_{2302}+\mathrm{X}_{2303}+\mathrm{X}_{2304 \ldots+\mathrm{X}_{2313} \leq 1}$

$\mathrm{X}_{2303}+\mathrm{X}_{2304}+\mathrm{X}_{2305 \ldots} \ldots+\mathrm{X}_{2314} \leq 1$

$\mathrm{X}_{2304}+\mathrm{X}_{2305}+\mathrm{X}_{2306} \ldots+\mathrm{X}_{2315} \leq 1$

$\mathrm{X}_{2305}+\mathrm{X}_{2305}+\mathrm{X}_{2306 \ldots+\mathrm{X}_{2316} \leq 1}$

$\mathrm{X}_{2305}+\mathrm{X}_{2306}+\mathrm{X}_{2307 \ldots+\mathrm{X}_{2317} \leq 2}$

$\mathrm{X}_{2306}+\mathrm{X}_{2307}+\mathrm{X}_{2308 \ldots+\mathrm{X}_{2317} \leq 1}$

$\mathrm{X}_{2306}+\mathrm{X}_{2307}+\mathrm{X}_{2308 \ldots} \ldots+\mathrm{X}_{2318} \leq 2$

$\ldots+\ldots+\ldots \quad \leq 1$

$\ldots+\ldots+\ldots \quad \leq 2$

$\mathrm{X}_{2340}+\mathrm{X}_{2341}+\mathrm{X}_{2342 \ldots} \ldots+\mathrm{X}_{2351} \leq 1$

$\mathrm{X}_{2340}+\mathrm{X}_{2341}+\mathrm{X}_{2342 \ldots} \ldots+\mathrm{X}_{2352} \leq 2$

$\mathrm{X}_{2341}+\mathrm{X}_{2342}+\mathrm{X}_{2343} \ldots+\mathrm{X}_{2352} \leq 1$

d. Jarak waktu antar pemeliharaan harus kurang dari 2 kali interval pemeliharaannya. Pada mesin yang memiliki interval waktu pemeliharaannya 500 jam, pemeliharaan tidak boleh berjarak lebih dari 11 minggu. Maka didapatkan persamaan sebagai berikut.

$\sum_{j=l}^{l+11} X_{i j} \geq 2$ untuk $l=k_{2}, k_{2}+1, \ldots, 41$

pada interval $500 \mathrm{jam}$

$\sum_{j=l}^{l+23} X_{i j} \geq 2$ untuk $l=k_{2}, k_{2}+1, \ldots, 29$

pada interval 1000 jam

Berdasarkan persamaan yang telah didapatkan maka diberikan contoh perhitungan untuk mesin ke 1 .

$k_{2}=\operatorname{roundup}\left(\frac{500-360}{14 * 6}\right)=2$

Maka persamaan pada mesin ke 1 adalah sebagai berikut.

$\mathrm{X}_{0102}+\mathrm{X}_{0103}+\mathrm{X}_{0104 \ldots} \ldots+\mathrm{X}_{0113} \geq 2$

$\mathrm{X}_{0103}+\mathrm{X}_{0104}+\mathrm{X}_{0105} \ldots+\mathrm{X}_{0114} \geq 2$

$\ldots+\ldots+\ldots \quad \geq 2$

$\mathrm{X}_{0141}+\mathrm{X}_{0142}+\mathrm{X}_{0143 \ldots} \ldots+\mathrm{X}_{0152} \geq 2$

Pada mesin yang memiliki interval waktu pemeliharaannya 1000 jam, pemeliharaan tidak boleh berjarak lebih dari 23 minggu. Maka didapatkan persamaan sebagai berikut. Sebagai contoh untuk mesin ke 23,

$k_{2}=$ roundup $\left(\frac{1000-600}{14 * 6}\right)=5$ 
maka persamaannya adalah sebagai berikut.

$X_{2305}+X_{2306}+X_{2307} \ldots+X_{2328} \geq 2$
$X_{2306}+X_{2307}+X_{2308} \ldots+X_{2329} \geq 2$
$\ldots+\ldots+\ldots$
$X_{2329}+X_{2330}+X_{2331} \ldots+X_{2352} \geq 2$

\section{Penetapan Fungsi Tujuan}

Fungsi tujuan model penjadwalan pemeliharaan preventif mesin-mesin produksi adalah minimasi total waktu keterlambatan aktivitas pemeliharaan preventif. Formulasi model penjadwalan pemeliharaan preventif mesinmesin produksi adalah sebagai berikut:

$\operatorname{Min} Z=\sum_{i=1}^{34}\left(W_{i}-I p_{i} \sum_{j=1}^{52} X_{i j}\right)$

dimana $W_{i}=$ Jam jalan mesin ke- $i$ sampai minggu ke 52.

$W_{i}=$ Jam jalan awal mesin ke- $i+$ (jam kerja mesin per hari $\mathrm{x}$ jumlah hari kerja per minggu $\mathrm{x}$ jumlah minggu per tahun)

$\mathrm{W}_{\mathrm{i}} \quad=\mathrm{J}_{\mathrm{i} 00}+4368$

e. Maka fungsi tujuan dapat dijabarkan sebagai berikut.

\begin{abstract}
$\operatorname{Min} Z=\left(4728-500 \sum_{\mathrm{j}=1}^{52} \mathrm{X}_{1 \mathrm{j}}\right)+\left(4728-500 \sum_{\mathrm{j}=1}^{52} \mathrm{X}_{2 \mathrm{j}}\right)+\left(4728-500 \sum_{\mathrm{j}=1}^{52} \mathrm{X}_{3 \mathrm{j}}\right)+$ $\left(4728-500 \sum_{\mathrm{j}=1}^{52} \mathrm{X}_{4 \mathrm{j}}\right)+\left(4728-500 \sum_{\mathrm{j}=1}^{52} \mathrm{X}_{5 \mathrm{j}}\right)+\left(4728-500 \sum_{\mathrm{j}=1}^{52} \mathrm{X}_{6 \mathrm{j}}\right)+$ $\left(4728-500 \sum_{\mathrm{j}=1}^{52} \mathrm{X}_{7 \mathrm{j}}\right)+\left(4728-500 \sum_{\mathrm{j}=1}^{52} \mathrm{X}_{8 \mathrm{j}}\right)+\left(4488-500 \sum_{\mathrm{j}=1}^{52} \mathrm{X}_{9 \mathrm{j}}\right)+$ $\left(4488-500 \sum_{\mathrm{j}=1}^{52} \mathrm{X}_{10 \mathrm{j}}\right)+\left(4848-500 \sum_{\mathrm{j}=1}^{52} \mathrm{X}_{11 \mathrm{j}}\right)+\left(4848-500 \sum_{\mathrm{j}=1}^{52} \mathrm{X}_{12 \mathrm{j}}\right)+$ $\left(4848-500 \sum_{\mathrm{j}=1}^{52} \mathrm{X}_{13 \mathrm{j}}\right)+\left(4848-500 \sum_{\mathrm{j}=1}^{52} \mathrm{X}_{14 \mathrm{j}}\right)+\left(4848-500 \sum_{\mathrm{j}=1}^{52} \mathrm{X}_{15 \mathrm{j}}\right)+$ $\left(4848-500 \sum_{\mathrm{j}=1}^{52} \mathrm{X}_{16 \mathrm{j}}\right)+\left(4488-500 \sum_{\mathrm{j}=1}^{52} \mathrm{X}_{17 \mathrm{j}}\right)+\left(4488-500 \sum_{\mathrm{j}=1}^{52} \mathrm{X}_{18 \mathrm{j}}\right)+$ $\left(4728-500 \sum_{\mathrm{j}=1}^{52} \mathrm{X}_{19 \mathrm{j}}\right)+\left(4728-500 \sum_{\mathrm{j}=1}^{52} \mathrm{X}_{20 \mathrm{j}}\right)+\left(4728-500 \sum_{\mathrm{j}=1}^{52} \mathrm{X}_{21 \mathrm{j}}\right)+$ $\left(4728-500 \sum_{\mathrm{j}=1}^{52} \mathrm{X}_{22 \mathrm{j}}\right)+\left(4968-1000 \sum_{\mathrm{j}=1}^{52} \mathrm{X}_{23 \mathrm{j}}\right)+\left(4968-1000 \sum_{\mathrm{j}=1}^{52} \mathrm{X}_{24 \mathrm{j}}\right)+$ $\left(4968-1000 \sum_{j=1}^{52} X_{25 j}\right)+\left(4968-1000 \sum_{j=1}^{52} X_{26 j}\right)+\left(4968-1000 \sum_{j=1}^{52} X_{27 j}\right)+$ $\left(5088-1000 \sum_{\mathrm{j}=1}^{52} \mathrm{X}_{28 \mathrm{j}}\right)+\left(5088-1000 \sum_{\mathrm{j}=1}^{52} \mathrm{X}_{29 \mathrm{j}}\right)+\left(5088-1000 \sum_{\mathrm{j}=1}^{52} \mathrm{X}_{30 \mathrm{j}}\right)+$ $\left(5088-1000 \sum_{\mathrm{j}=1}^{52} \mathrm{X}_{31 \mathrm{j}}\right)+\left(5088-1000 \sum_{\mathrm{j}=1}^{52} \mathrm{X}_{32 \mathrm{j}}\right)+\left(4848-1000 \sum_{\mathrm{j}=1}^{52} \mathrm{X}_{33 \mathrm{j}}\right)+$

$\left(4848-1000 \sum_{\mathrm{j}=1}^{52} \mathrm{X}_{34 \mathrm{j}}\right)$

\section{Output Model}

Berdasarkan formulasi model yang telah dilakukan, diketahui bahwa model memiliki 4 fungsi kendala yang harus dipenuhi. Fungsi tujuan model ini adalah untuk meminimasi keterlambatan pemeliharaan preventif. Selanjutnya model dijalankan dengan bantuan Software Lingo 17.0 untuk mendapatkan nilai keterlambatan pemeliharaan preventif mesin. Adapun hasil yang didapatkan menggunakan Lingo 17.0 ditampilkan pada Gambar 2.

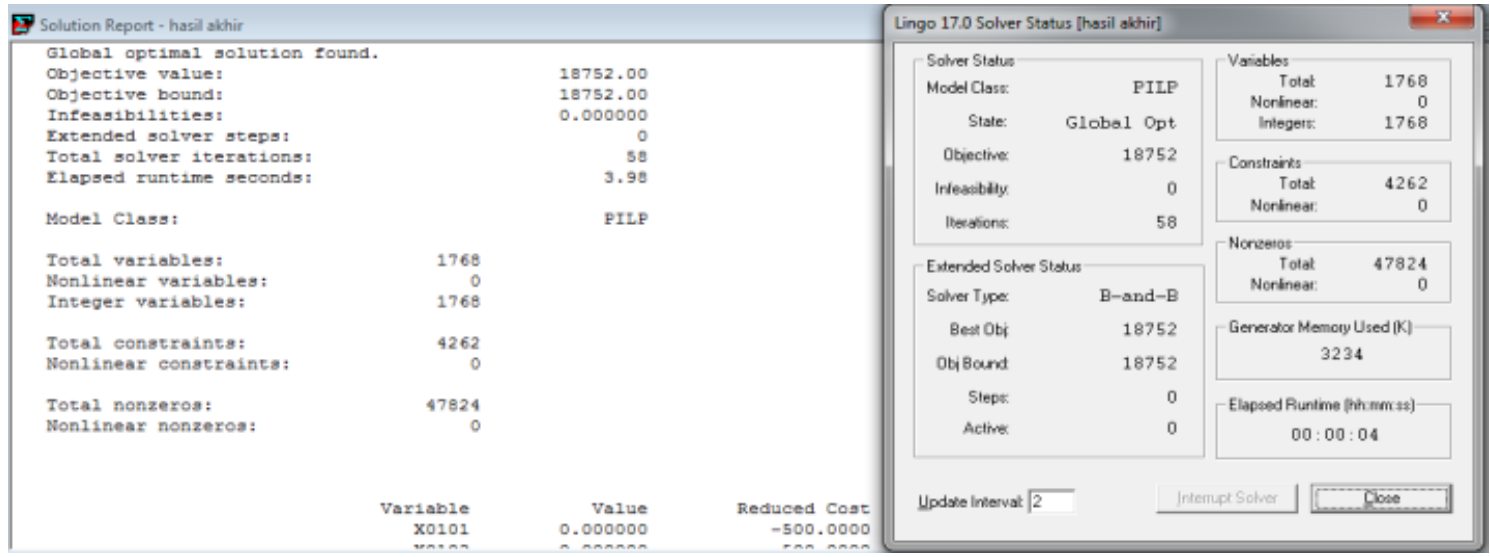

Gambar 2. Output Lingo 17.0 yang Menunjukkan Hasil Keterlambatan untuk 34 Mesin

Berdasarkan Gambar 2 diketahui bahwa nilai keterlambatan yang didapatkan untuk 34 mesin produksi selama 52 minggu kedepan adalah 18752 jam. Hasil keluaran Lingo 17.0 berupa nilai-nilai untuk setiap variabel yang ada dan nilai keterlambatan. Keluaran Lingo 17.0 selanjutnya dijadikan Gantt Chart usulan penjadwalan seperti Gambar 3.

\section{Verifikasi dan Validasi Model}

Tahapan pengujian model terdiri dari verifikasi dan validasi.

\section{Verifikasi Model}

Verifikasi model dilakukan bertujuan untuk memeriksa kesesuaian hasil yang diperoleh dari model dengan konsep model. Verifikasi model dilakukan dengan dua metode yakni uji dimensi dan inspeksi model. Uji dimensi berguna untuk memastikan bahwa dimensi output dengan input atau kesamaan dimensi antara ruas kiri dengan ruas kanan dari model. Tahapan uji dimensi model terdiri dari: 


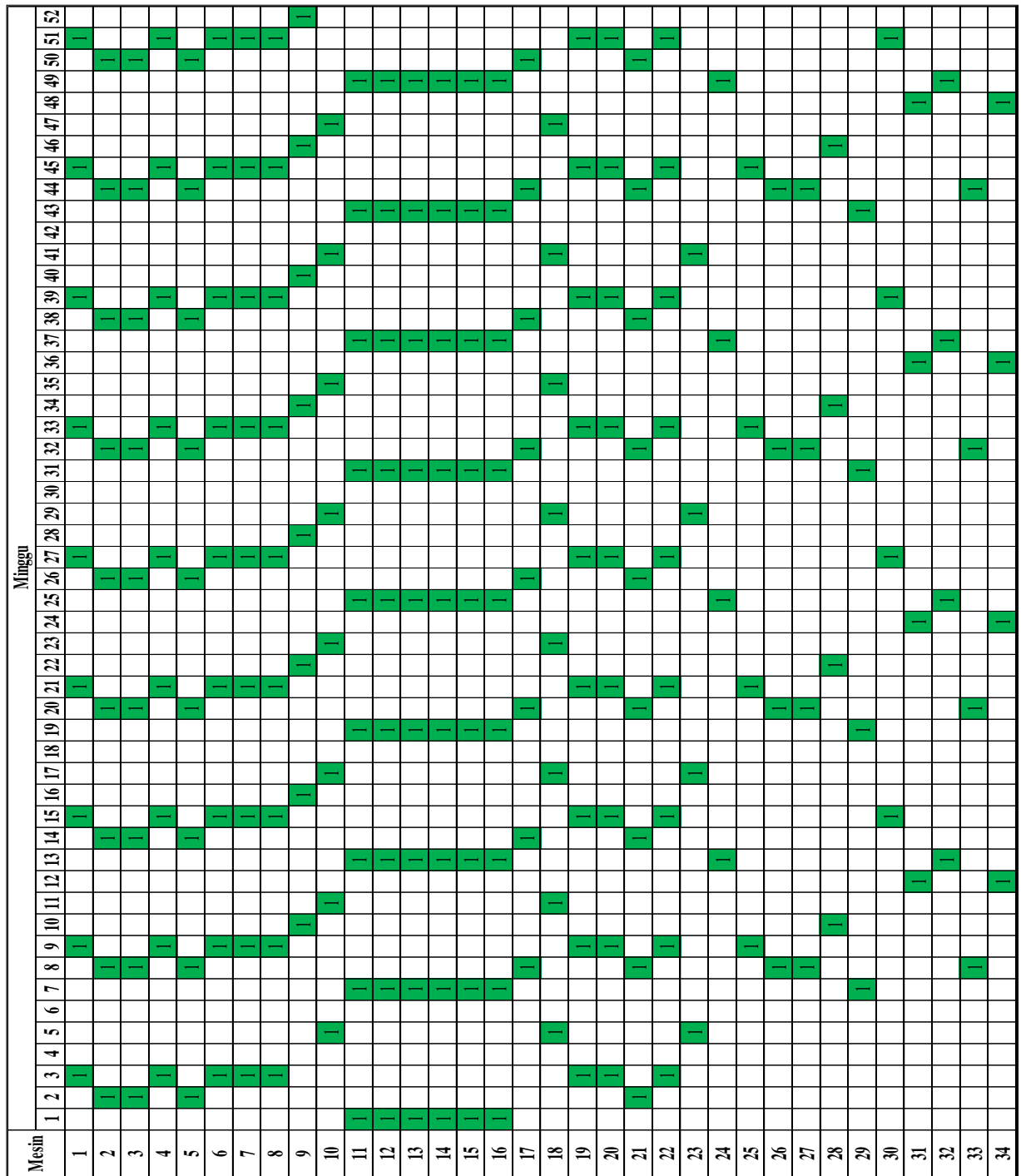

Gambar 3. Gantt chart Usulan Penjadwalan Pemeliharaan Preventif Mesin-mesin Produksi di PT JSI

\section{a. Uji Dimensi pada Fungsi Kendala}

$$
\begin{array}{ll}
\text { Kendala Pertama } & \\
\sum_{i=1}^{34}\left(\operatorname{Lp}_{i} \times T k_{i}\right) X_{i j} & \leq \text { Jkhm } \times \mathrm{Tk} \\
\left.\sum_{i=1}^{34} \text { jam } \times \text { Orang }\right) X_{i j} & \leq \text { jam } \times \text { orang } \\
\text { jam } x \text { Orang } & \leq \text { jam } x \text { orang }
\end{array}
$$

Kendala Kedua

$$
\begin{array}{ll}
\sum_{j=1}^{52} X_{i j} & \leq \operatorname{Int}\left(\left(J_{i 00}+(J h k \times J k m)\right) \div I p_{i}\right) \\
\text { tanpa satuan } & \leq \operatorname{Int}((j a m+(\text { hari } \times j a m / h a r i)) \div \text { jam }) \\
\text { tanpa satuan } & \leq \operatorname{Int}((j a m+j a m) \div j a m) \\
\text { tanpa satuan } & \leq \operatorname{Int}(\text { jam } \div \text { jam }) \\
\text { tanpa satuan } & \leq \text { tanpa satuan }
\end{array}
$$

Kendala Ketiga

$\sum_{j=1}^{k_{1}} X_{i j}$

tanpa satuan

$$
\begin{aligned}
& \leq 0 \\
& \leq \text { tanpa satuan }
\end{aligned}
$$$$
\sum_{j=1}^{k_{2}} X_{i j} \leq 1
$$$$
\text { tanpa satuan }
$$$$
\sum_{j=l}^{l+5} X_{i j} \leq 1
$$$$
\text { tanpa satuan }
$$

$\sum_{j=l}^{l+6} X_{i j} \leq 2$

tanpa satuan

$\leq$ tanpa satuan

Kendala Keempat

$\sum_{j=l}^{l+11} X_{i j} \geq 2$

tanpa satuan $\quad \leq$ tanpa satuan

\section{b. Uji Dimensi pada Fungsi Tujuan}

$$
\begin{aligned}
\operatorname{Min} Z & =\sum_{i=1}^{34}\left(\left(\mathrm{~J}_{\mathrm{i} 00}+4368\right)-I p_{i} \sum_{j=1}^{52} X_{i j}\right) \\
\operatorname{Jam} & =((J a m+J a m)-J a m) \\
\text { Jam } & =J a m
\end{aligned}
$$

Berdasarkan uji dimensi didapatkan hasil bahwa dimensi model antara ruas kiri dan ruas kanan sudah sesuai. Maka dapat disimpulkan bahwa model telah memenuhi tahapan uji dimensi. Tahapan verifikasi selanjutnya dengan metode inspeksi pada masing-masing komponen dalam model.

\section{Verifikasi Fungsi Kendala pada Model}


Tahap ini bertujuan untuk membuktikan solusi yang didapatkan tidak melanggar fungsi kendala yang ada. Verifikasi model dilakukan dengan mencari solusi model dengan jumlah mesin lebih sedikit. Verifikasi dilakukan dengan percobaan pada 3 dan 4 buah mesin produksi. Berikut adalah nilai keputusan yang didapatkan untuk percobaan 3 mesin dan 4 mesin yang ditampilkan dalam Tabel 5 dan Tabel 6.

Tabel 5. Nilai Keputusan dari Percobaan dengan 3 Buah Mesin

\begin{tabular}{|c|c|c|c|c|c|c|c|c|c|c|c|c|c|c|c|c|c|c|c|c|}
\hline \multicolumn{10}{|c|}{ Minggu } \\
\hline Mesin & $\mathbf{1}$ & $\mathbf{2}$ & $\mathbf{3}$ & $\mathbf{8}$ & $\mathbf{9}$ & $\mathbf{1 4}$ & $\mathbf{1 5}$ & $\mathbf{2 0}$ & $\mathbf{2 1}$ & $\mathbf{2 6}$ & $\mathbf{2 7}$ & $\mathbf{3 2}$ & $\mathbf{3 3}$ & $\mathbf{3 8}$ & $\mathbf{3 9}$ & $\mathbf{4 4}$ & $\mathbf{4 5}$ & $\mathbf{5 0}$ & $\mathbf{5 1}$ & $\mathbf{5 2}$ \\
\hline 1 & & 1 & & 1 & & 1 & & 1 & & 1 & & 1 & & 1 & & 1 & & 1 & & \\
\hline 2 & & 1 & & 1 & & 1 & & 1 & & 1 & & 1 & & 1 & & 1 & & 1 & & \\
\hline 3 & & 1 & & 1 & & 1 & & 1 & & 1 & & 1 & & 1 & & 1 & & 1 & & \\
\hline
\end{tabular}

Tabel 6. Nilai Keputusan dari Percobaan dengan 4 Buah Mesin

\begin{tabular}{|c|c|c|c|c|c|c|c|c|c|c|c|c|c|c|c|c|c|c|c|c|}
\hline \multicolumn{10}{|c|}{ Minggu } \\
\hline Mesin & $\mathbf{1}$ & $\mathbf{2}$ & $\mathbf{3}$ & $\mathbf{8}$ & $\mathbf{9}$ & $\mathbf{1 4}$ & $\mathbf{1 5}$ & $\mathbf{2 0}$ & $\mathbf{2 1}$ & $\mathbf{2 6}$ & $\mathbf{2 7}$ & $\mathbf{3 2}$ & $\mathbf{3 3}$ & $\mathbf{3 8}$ & $\mathbf{3 9}$ & $\mathbf{4 4}$ & $\mathbf{4 5}$ & $\mathbf{5 0}$ & $\mathbf{5 1}$ & $\mathbf{5 2}$ \\
\hline 1 & & 1 & & 1 & & 1 & & 1 & & 1 & & 1 & & 1 & & 1 & & 1 & & \\
\hline 2 & & & 1 & & 1 & & 1 & & 1 & & 1 & & 1 & & 1 & & 1 & & 1 & \\
\hline 3 & & & 1 & & 1 & & 1 & & 1 & & 1 & & 1 & & 1 & & 1 & & 1 & \\
\hline 4 & & & 1 & & 1 & & 1 & & 1 & & 1 & & 1 & & 1 & & 1 & & 1 & \\
\hline
\end{tabular}

Berdasarkan Tabel 5 dan Tabel 6 diketahui nilai keputusan yang didapatkan untuk 3 mesin dan 4 mesin. Hasil ini diverifikasi dengan kendalakendala yang ada pada model.
Kendala pertama yakni jam kerja orang yang dibutuhkan tidak boleh melebihi jam kerja orang yang tersedia yakni 40 jam. Adapun jam orang yang didapatkan dari percobaan untuk 3 mesin dan 4 mesin disajikan dalam Tabel 7 dan Tabel 8.

Tabel 7. Jam Kerja Orang Berdasarkan Nilai Keputusan dari Percobaan dengan 3 Buah Mesin

\begin{tabular}{|l|c|c|c|c|c|c|c|c|c|c|c|c|c|c|c|c|c|c|c|c|}
\hline Minggu & 1 & 2 & 3 & 8 & 9 & 14 & 15 & 20 & 21 & 26 & 27 & 32 & 33 & 38 & 39 & 44 & 45 & 50 & 51 & 52 \\
\hline $\begin{array}{l}\text { Jam kerja orang } \\
\text { yang dibutuhkan }\end{array}$ & 0 & 9 & 0 & 9 & 0 & 9 & 0 & 9 & 0 & 9 & 0 & 9 & 0 & 9 & 0 & 9 & 0 & 9 & 0 & 0 \\
\hline $\begin{array}{l}\text { Jam kerja orang } \\
\text { yang tersedia }\end{array}$ & 40 & 40 & 40 & 40 & 40 & 40 & 40 & 40 & 40 & 40 & 40 & 40 & 40 & 40 & 40 & 40 & 40 & 40 & 40 & 40 \\
\hline
\end{tabular}

Tabel 8. Jam Kerja Orang Berdasarkan Nilai Keputusan dari Percobaan dengan 4 Buah Mesin

\begin{tabular}{|l|c|c|c|c|c|c|c|c|c|c|c|c|c|c|c|c|c|c|}
\hline Minggu & 1 & 2 & 3 & 4 & 8 & 9 & 10 & 14 & 15 & 16 & $\ldots$ & 40 & 44 & 45 & 46 & 50 & 51 & 52 \\
\hline $\begin{array}{l}\text { Jam kerja orang yang } \\
\text { dibutuhkan }\end{array}$ & 0 & 3 & 11 & 0 & 3 & 11 & 0 & 3 & 11 & 0 & $\ldots$ & 0 & 3 & 11 & 0 & 3 & 11 & 0 \\
\hline $\begin{array}{l}\text { Jam kerja orang yang } \\
\text { tersedia }\end{array}$ & 40 & 40 & 40 & 40 & 40 & 40 & 40 & 40 & 40 & 40 & $\ldots$ & 40 & 40 & 40 & 40 & 40 & 40 & 40 \\
\hline
\end{tabular}

Berdasarkan Tabel 7 dan Tabel 8 diketahui bahwa jam kerja orang yang didapatkan tidak melebihi jam kerja orang tersedia. Maka dapat disimpulkan bahwa kendala pertama terpenuhi.

Kendala kedua adalah jumlah pemeliharaan preventif tidak boleh melebihi target yang ditetapkan. Pada mesin 3 dan mesin 4 target yang didapatkan adalah 9 kali. Adapun jumlah pemeliharaan preventif yang didapatkan pada percobaan 3 mesin dan 4 mesin dapat dilihat pada Tabel 5 dan 6. Jumlah pemeliharaan preventif yang didapatkan pada kedua percobaan adalah 9 kali. Maka dapat disimpulkan bahwa kendala kedua terpenuhi.

Kendala ketiga adalah pemeliharaan preventif dilakukan ketika waktu jalan mesin melebihi 
interval waktu pemeliharaannya. Interval pemeliharaan pada mesin 1 hingga 4 adalah 500 jam. Jika interval pemeliharaan preventifnya 500 jam maka jarak minimal antar pemeliharaan preventif adalah 6 minggu. Berdasarkan Tabel 5 dan 6 diketahui bahwa jarak antar pemeliharaan preventif pada mesin selalu dengan jarak 6 minggu. Maka dapat disimpulkan bahwa kendala ketiga terpenuhi.

Kendala keempat adalah jarak waktu antar pemeliharaan harus kurang dari 2 kali interval pemeliharaannya. Pada mesin 1 sampai 4 interval waktu pemeliharaannya 500 jam, yang berarti jarak antar pemeliharaan tidak boleh berjarak lebih dari 11 minggu. Berdasarkan Tabel 5 dan 6 diketahui bahwa jarak antar pemeliharaan preventif adalah 6 minggu dan tidak ada yang melebihi 11 minggu. Maka dapat disimpulkan bahwa kendala keempat terpenuhi.
Berdasarkan percobaan yang telah dilakukan sebelumnya, diketahui bahwa kendala-kendala pada model terpenuhi dengan nilai keputusan yang didapatkan berbeda.

\section{Verifikasi Fungsi Tujuan pada Model}

Langkah ini bertujuan untuk memastikan bahwa nilai keterlambatan yang didapat dari model bernilai benar. Verifikasi dilakukan dengan membandingkan hasil yang didapatkan menggunakan dua software yang berbeda. Software yang digunakan adalah Lingo 17.0 dan Microsoft Excel. Percobaan dilakukan seperti sebelumnya yakni pada 3 mesin dan 4 mesin. Adapun nilai keterlambatan pada 3 mesin dan 4 mesin menggunakan Lingo 17.0 ditampilkan pada Gambar 4.

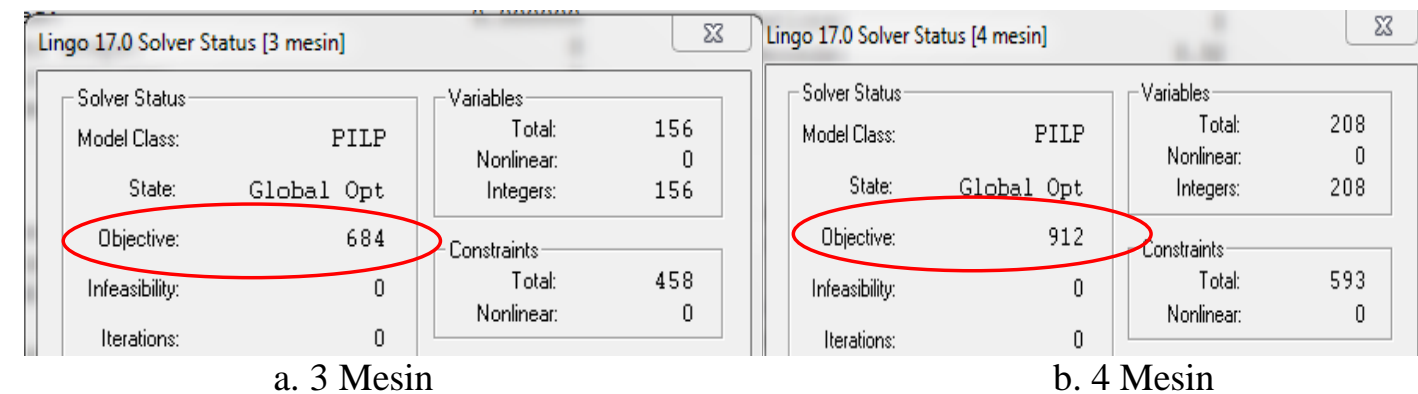

Gambar 4. Keluaran Lingo 17.0 yang Menunjukkan Hasil Keterlambatan Mesin

Berdasarkan Gambar 4 diketahui bahwa terjadi keterlambatan pada percobaan 3 mesin selama 684 jam dan keterlambatan pada percobaan 4 mesin selama 912 jam. Selanjutnya akan dihitung keterlambatan mesin menggunakan Microsoft Excel yang disajikan pada Tabel 9 dan Tabel 10.

Tabel 9. Nilai Keterlambatan 3 Mesin Menggunakan Microsoft Excel

\begin{tabular}{|c|c|c|c|c|}
\hline $\begin{array}{c}\text { Nomor } \\
\text { Mesin }\end{array}$ & $\begin{array}{c}\text { Jam Jalan Mesin } \\
\text { Selama Periode } \\
\text { Perencanaan (jam) }\end{array}$ & $\begin{array}{c}\text { Frekuensi } \\
\text { Pemeliharaan } \\
\text { Preventif }\end{array}$ & $\begin{array}{c}\text { Interval } \\
\text { Pemeliharaan } \\
\text { Preventif (jam) }\end{array}$ & $\begin{array}{c}\text { Keterlambatan } \\
\text { Pemeliharaan } \\
\text { Preventif (jam) }\end{array}$ \\
\hline 1 & 4728 & 9 & 500 & 228 \\
2 & 4728 & 9 & 500 & 228 \\
3 & 4728 & 9 & 500 & 228 \\
\hline \multicolumn{4}{|c|}{ Total } \\
\hline
\end{tabular}

Tabel 10. Nilai Keterlambatan 4 Mesin Menggunakan Microsoft Excel

\begin{tabular}{|c|c|c|c|c|}
\hline $\begin{array}{c}\text { Nomor } \\
\text { Mesin }\end{array}$ & $\begin{array}{c}\text { Jam Jalan Mesin } \\
\text { Selama Periode } \\
\text { Perencanaan (jam) }\end{array}$ & $\begin{array}{c}\text { Frekuensi } \\
\text { Pemeliharaan } \\
\text { Preventif }\end{array}$ & $\begin{array}{c}\text { Interval } \\
\text { Pemeliharaan } \\
\text { Preventif (jam) }\end{array}$ & $\begin{array}{c}\text { Keterlambatan } \\
\text { Pemeliharaan } \\
\text { Preventif (jam) }\end{array}$ \\
\hline 1 & 4728 & 9 & 500 & 228 \\
2 & 4728 & 9 & 500 & 228 \\
3 & 4728 & 9 & 500 & 228 \\
4 & 4728 & 9 & \multicolumn{4}{|c|}{ Total } \\
\hline \multicolumn{4}{|c|}{}
\end{tabular}

Perhitungan keterlambatan pada percobaan 3 mesin.
Keterlambatan $=$ Lama periode perencanaan (frekuensi pemeliharaan $\mathrm{x}$ interval) 
$=4728-9 \times 500$

$=4728-4500$

$=228$ jam

Total Keterlambatan $=\sum_{\mathrm{i}=1}^{3}$ Keterlambatan

$=228+228+228$

$=684 \mathrm{jam}$

Berdasarkan Tabel 9 dan Tabel 10 diketahui bahwa keterlambatan yang terjadi pada percobaan 3 mesin dan 4 mesin terjadi selama 680 jam dan 912 jam. Maka diketahui bahwa nilai keterlambatan yang didapatkan pada Software Lingo 17.0 dan
Microsoft Excel adalah sama dan dapat disimpulkan bahwa fungsi tujuan pada model telah terverifikasi.

\section{Validasi Model}

Validasi model penjadwalan pemeliharaan preventif mesin-mesin produksi dilakukan menggunakan validitas konstruk. Tahapan validasi dengan metode validitas konstruk disajikan pada Tabel 11.

Tabel 11. Validasi dengan Validitas Konstruk

\begin{tabular}{|c|c|c|c|}
\hline No & Elemen & Uraian & Kesimpulan \\
\hline 1 & $\begin{array}{l}\text { Karakteristik } \\
\text { Sistem }\end{array}$ & $\begin{array}{l}\text { Sistem yang dibahas pada permasalahan adalah sistem penjadwalan } \\
\text { pemeliharaan preventif. Karakteristik pada sistem mencakup komponen- } \\
\text { komponen seperti jam jalan mesin ke-i sampai perencanaan dilakukan, jam kerja } \\
\text { mesin per hari, jumlah hari kerja per minggu, jumlah minggu per tahun, tenaga } \\
\text { kerja tersedia, jumlah tenaga kerja yang dibutuhkan untuk pemeliharaan } \\
\text { preventif mesin ke-i, jam kerja untuk pemeliharaan preventif pada hari minggu, } \\
\text { jumlah hari kerja dalam setahun, lama waktu pemeliharaan preventif mesin ke- } \\
\text { i, interval pemeliharaan mesin ke-i, jam jalan mesin ke-i, total waktu jalan mesin } \\
\text { ke-i dalam } 1 \text { tahun, waktu keterlambatan pemeliharaan preventif mesin. }\end{array}$ & $\begin{array}{l}\text { Telah dimasukkan dan } \\
\text { dicantumkan pada } \\
\text { model }\end{array}$ \\
\hline \multirow{3}{*}{2} & $\begin{array}{l}\text { Formulasi } \\
\text { Tujuan } \\
\text { penjadwalan }\end{array}$ & $\begin{array}{l}\text { Minimasi total keterlambatan pemeliharaan preventif mesin dari interval } \\
\text { pemeliharaan preventif yang telah ditetapkan dan mampu menunjukkan nilai } \\
\text { keterlambatan pelaksanaan pemeliharaan preventif masing-masing mesin. }\end{array}$ & $\begin{array}{l}\text { Telah dijadikan } \\
\text { sebagai fungsi tujuan }\end{array}$ \\
\hline & $\begin{array}{l}\text { Batasan } \\
\text { yang harus } \\
\text { dipenuhi }\end{array}$ & $\begin{array}{l}\text { Kendala yang ada dalam penjadwalan pemeliharaan preventif telah } \\
\text { dicantumkan sebagai fungsi kendala dalam model }\end{array}$ & $\begin{array}{l}\text { Telah dimasukkan } \\
\text { sebagai fungsi kendala }\end{array}$ \\
\hline & $\begin{array}{l}\text { Keputusan } \\
\text { yang harus } \\
\text { diambil }\end{array}$ & $\begin{array}{l}\text { Aktivitas pemeliharaan preventif masing-masing mesin dapat terjadwalkan pada } \\
\text { minggu ke-j selama periode perencanaan. Aktivitas pemeliharaan preventif } \\
\text { mesin ke-i dilakukan pada minggu ke-j untuk semua mesin dan } 52 \text { minggu dalam } \\
1 \text { tahun. }\end{array}$ & $\begin{array}{l}\text { Telah dimasukkan } \\
\text { dalam model sebagai } \\
\text { variabel keputusan }\end{array}$ \\
\hline
\end{tabular}

Berdasarkan Tabel 11 diketahui bahwa pada semua karakteristik sistem telah dimasukkan dalam pembuatan model. Fungsi tujuan mampu menunjukkan keterlambatan, fungsi kendala telah mencakup kendala pada sistem, dan keluaran untuk variabel keputusan telah didapatkan. Maka dapat disimpulkan bahwa model penjadwalan pemeliharaan preventif telah valid.

\section{Analisis Model}

Model mampu menghasilkan usulan jadwal pemeliharaan preventif untuk mesin-mesin produksi di PT JSI selama 52 minggu (1 tahun) untuk meminimasi keterlambatan. Sebagai contoh implementasi model, output pada mesin nomor 1 adalah dilakukan pemeliharaan preventif pada minggu ke 3, 9, 15, 21, 27, 33, 39, 45, dan 51 . Berdasarkan usulan model, diperoleh total keterlambatan selama 18752 jam. Hasil ini didapatkan dengan mengikuti semua kendala yang ada sehingga tidak ada kendala yang dilanggar. Data yang digunakan kendala pada model dibuat berdasarkan data yang diperoleh dari perusahaan. Data yang dibutuhkan untuk pembuatan model adalah jam jalan mesin ke-i sampai perencanaan dilakukan, jam kerja mesin per hari, jumlah hari kerja per minggu, jumlah minggu per tahun, tenaga kerja tersedia, jumlah tenaga kerja yang dibutuhkan untuk pemeliharaan preventif mesin ke-i, jam kerja untuk pemeliharaan preventif pada hari minggu, jumlah hari kerja dalam setahun, lama waktu pemeliharaan preventif mesin ke-i, dan interval pemeliharaan mesin ke-i, jam jalan mesin ke-i, dan total waktu jalan mesin ke-i dalam 1 tahun.

Data yang masih perlu diperbaiki oleh perusahaan adalah data realisasi jam jalan mesin per hari agar hasil yang didapatkan lebih baik. Di samping itu perusahaan perlu mencatat dengan baik setiap aktivitas pemeliharaan preventif yang dilakukan agar hasil penjadwalan yang diperoleh dari model dapat dibandingkan dengan jadwal aktual yang diterapkan perusahaan. Walaupun dalam penelitian ini hal tersebut belum dapat dilakukan, namun pendekatan ILP yang digunakan merupakan algoritma solusi eksak sehingga dapat menjamin bahwa solusi yang diperoleh adalah 
optimal untuk semua kendala yang ditetapkan dalam model.

\section{Analisis Sensitivitas}

Analisis sensitivitas dilakukan dengan mengubah nilai parameter model pada fungsi kendala yaitu lama waktu pemeliharaan, jumlah tenaga kerja yang tersedia, jam kerja mesin perhari, dan jam kerja tersedia untuk pemeliharaan.

Pada parameter lama waktu pemeliharaan, nilai parameter diubah untuk semua mesin dengan mengurangi lama waktu pemeliharaan sebesar 15 menit, menambah waktu selama 15 menit, 30 menit, 45 menit, 60 menit, dan 180 menit. Dengan menggunakan Software Lingo 17.0, diperoleh nilai keterlambatan untuk perubahan pengurangan 15 menit, penambahan 15 menit, 30 menit, 45 menit, 60 menit adalah 18752 jam. Hasil yang didapatkan dengan menambahkan 180 menit lama waktu pemeliharaan adalah infeasible yang berarti perubahan parameter lama waktu pemeliharaan tidak bisa dilakukan jika penambahan lama waktu pemeliharaan 180 menit atau lebih. Hasil perubahan parameter lama waktu pemeliharaan disajikan dalam bentuk grafik pada Gambar 5.

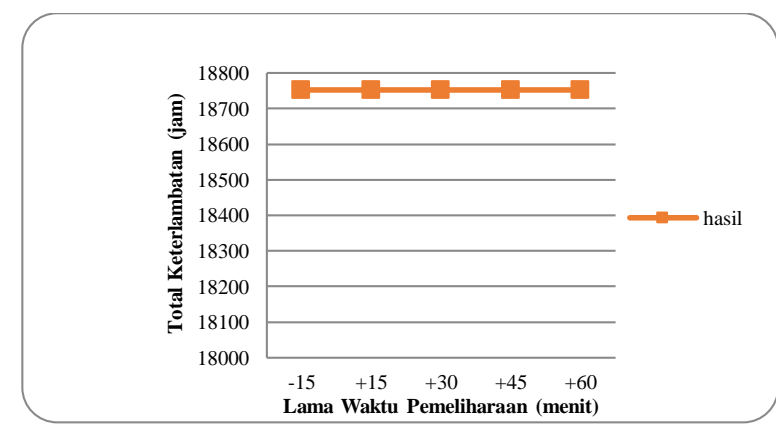

Gambar 5. Grafik Perubahan Parameter Lama

Waktu Pemeliharaan Terhadap Total

Keterlambatan Pemeliharaan Preventif

Berdasarkan Gambar 5 terlihat bahwa ketika perubahan parameter dilakukan dengan pengurangan 15 menit, penambahan 15 menit, 30 menit, 45 menit, 60 menit terbentuk garis lurus yang berarti nilai keterlambatan yang didapatkan sama. Maka dapat disimpulkan bahwa model tidak sensitif terhadap perubahan parameter lama waktu pemeliharaan.

Parameter berikutnya yang akan diubah adalah jumlah tenaga kerja yang tersedia. Jumlah tenaga kerja yang tersedia pada perusahaan berjumlah 5 orang. Parameter ini diubah menjadi 2 orang, 3 orang, 4 orang, 6 orang, dan 7 orang. Dengan menggunakan Software Lingo 17.0, diperoleh nilai keterlambatan pada parameter dengan nilai perubahan 4 orang, 6 orang, dan 7 orang adalah 18752 jam. Nilai keterlambatan yang didapatkan ketika parameter 3 orang adalah 19252 jam. Ketika parameter diubah menjadi 2 orang, hasil yang didapatkan adalah infeasible yang berarti pemeliharaan preventif tidak bisa dilakukan jika dilakukan oleh 2 orang. Hasil dari perubahan parameter tersebut ditunjukkan dalam Gambar 6.

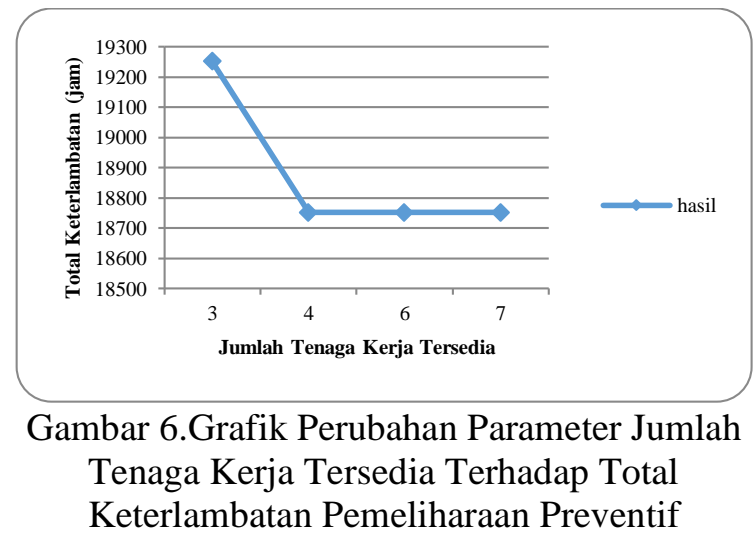

Dari Gambar 6 diketahui bahwa total keterlambatan naik ketika nilai parameter 3 orang kemudian turun ketika bernilai 4 orang dan nilainya tetap hingga nilai parameter 6 orang, dan 7 orang. Maka dapat disimpulkan bahwa model tidak sensitif terhadap perubahan parameter jumlah tenaga kerja tersedia ketika nilainya 4 orang atau lebih.

Parameter selanjutnya adalah jam kerja mesin per hari yang awalnya 14 jam diganti dengan 8 jam, 20 jam, dan 24 jam. Perubahan jam kerja mesin akan mempengaruhi fungsi tujuan, kendala kedua, kendala ketiga dan kendala keempat. Dengan menggunakan Software Lingo 17.0, diperoleh nilai keterlambatan ketika parameter diubah menjadi 8 jam dan 20 jam. Ketika parameter bernilai 8 jam nilai keterlambatan yang didapatkan adalah 21104 jam dan ketika parameter bernilai 20 jam hasil yang didapatkan adalah 44640 jam namun ketika parameter bernilai 24 jam hasil yang didapatkan adalah infeasible. Hasil perubahan parameter jam kerja per hari dapat dilihat pada Gambar 7.

Gambar 7 menunjukkan bahwa nilai keterlambatan dari 8 jam ke 14 jam mengalami penurunan dan ketika jam kerja 14 jam sampai 20 jam nilai keterlambatan mengalami kenaikan. Ketika jam kerja mesin perhari adalah 24 jam, tidak didapatkan solusi nilai keterlambatan. Maka dapat disimpulkan bahwa model sensitif terhadap perubahan parameter jam kerja mesin per hari.

Parameter selanjutnya adalah jam kerja tersedia untuk pemeliharaan yang awalnya selama 8 jam diubah menjadi 9 jam dan 10 jam. Dengan 
menngunakan Software Lingo 17.0, diperoleh bahwa keterlambatan yang didapatkan adalah 18752 jam untuk perubahan parameter menjadi 9 jam dan 10 jam. Hasil Perubahan parameter jam kerja tersedia untuk pemeliharaan ditampilkan pada Gambar 8.

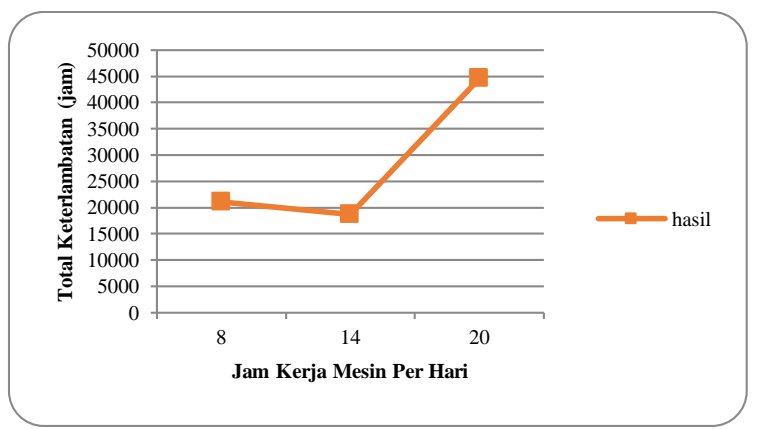

Gambar 7. Grafik Perubahan Parameter Jam Kerja Mesin Per Hari Terhadap Total Keterlambatan Pemeliharaan Preventif

Gambar 8 memperlihatkan garis lurus yang berarti tidak ada perubahan total keterlambatan ketika nilai parameter diubah. Hal ini menunjukkan model tidak sensitif terhadap perubahan parameter jam kerja tersedia untuk pemeliharaan.

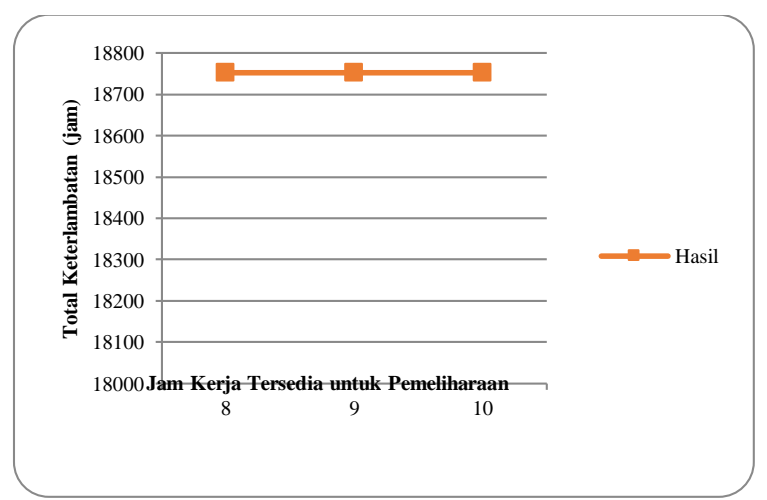

Gambar 8. Grafik Perubahan Parameter Jam Kerja

Tersedia Terhadap Total Keterlambatan

Pemeliharaan Preventif

Berdasarkan analisis sensitivitas yang telah dilakukan maka diketahui bahwa model sensitif terhadap perubahan parameter jam kerja mesin per hari dan tidak sensitif pada perubahan parameter lama waktu pemeliharaan, jam kerja tersedia untuk pemeliharaan, jumlah tenaga kerja tersedia ketika nilainya 4 orang atau lebih.

\section{KESIMPULAN}

Berdasarkan pengolahan data dan analisa yang dilakukan pada penelitian ini dapat disimpulkan bahwa model yang dibuat mampu untuk menghasilkan usulan penjadwalan pemeliharaan preventif untuk 34 mesin produksi di PT JSI, nilai total keterlambatan pemeliharaan preventif mesinmesin produksi di PT JSI untuk 34 mesin selama 52 minggu kedepan adalah 18.752 jam, dan berdasarkan analisis sensitivitas yang telah dilakukan maka diketahui bahwa model sensitif terhadap perubahan parameter jam kerja mesin per hari dan tidak sensitif pada perubahan parameter lama waktu pemeliharaan, jumlah tenaga kerja tersedia ketika nilainya 4 orang atau lebih, dan jam kerja tersedia untuk pemeliharaan.

Untuk pengembangan lebih lanjut dari model ini, jam kerja mesin per minggu sebaiknya mengikuti hari kerja aktual sesuai kalender kerja perusahaan. Di samping itu perlu dikaji konsekuensi biaya yang ditimbulkan akibat jadwal pemeliharaan preventif yang diperoleh.

\section{UCAPAN TERIMA KASIH}

Penulis menyampaikan terima kasih kepada Jurusan Teknik Industri, Fakultas Teknik, Universitas Andalas atas dukungan dan pembiayaan yang diberikan untuk penelitian ini.

\section{DAFTAR PUSTAKa}

[1] Milana, M., M.K. Khan, and J.E. MuniveHernandez, Design and development of Knowledge Based System for Integrated Maintenance Strategy and Operations. Concurrent Engineering, 2017. 25(1): p. 5-18.

[2] Peters, R.W., Maintenance Benchmarking and Best Practices: A Profit- and Customer-Centered Approach. 2006, USA: McGraw-Hill.

[3] Priyanta, D., Keandalan dan Perawatan. 2000, Jurusan Teknik Sistem Perkapalan, Fakultas Teknologi Kelautan: Institut Teknologi Sepuluh November.

[4] Mobley, R.K., Maintenance Fundamental, ed. n. Edition. 2004, USA Butterworth Heinemann.

[5] Ben-Daya, M., S.O. Duffuaa, A. Raouf, J. Knezevic , and D. Ait-Kadi, Handbook of Maintenance Management and Enggineering. 2009, London: Springer.

[6] Taufik, T. and S. Septyani, Penentuan Interval Waktu Perawatan Komponen Kritis pada Mesin Turbin di PT PLN (Persero) Sektor Pembangkit Ombilin. 2016, 2016. 14(2): p. 21.

[7] Dhillon, B.S., Maintainability, Maintenance, and Reliability for Engineers. 2006, USA CRC Press Taylor \& Francis Group LLC.

[8] Dhillon, B.S., Engineering Maintenance: A Modern Approach 2002, Boca Raton: CRC Press. 224.

[9] Wirdianto, E. and E.C. Arnes, Model Zero-One Linear Programming untuk Penjadwalan Raw Mill 
dan Cement Mill. Jurnal Optimasi Sistem Industri, 2018. 17(1): p. 64-74.

[10] Livia, C.Y. and T. Oktiarso, Penjadwalan Untuk Memininimalkan Total Tardiness Dengan Metode Integer Linear Programming. 2017, 2017. 18(2): p. 11.

\section{Biodata Penulis}

Eri Wirdianto, memperoleh gelar Sarjana Teknik dari Jurusan Teknik Industri, Universitas Sumatera Utara, dan Master of Science dari University of Bradford, UK. Ia bekerja sebagai dosen di Jurusan Teknik Industri Universitas Andalas sejak 1998 sampai sekarang. Bidang penelitiannya adalah simulasi, riset operasi, statistika, dan sistem distribusi dan transportasi dalam lingkup perancangan dan optimasi sistem industri.

Irfan Nugraha Putra Mukhti, menyelesaikan pendidikan sarjana di Jurusan Teknik Industri Universitas Andalas. Spesialisasi keahliannya adalah bidang manajemen pemeliharaan.
Alexie Herryandie Bronto Adi, menyelesaikan pendidikan Sarjana Teknik di Jurusan Teknologi Industri Pertanian, Institut Pertanian Bogor, dan pendidikan Magister dan Doktor di Institut Teknologi Sepuluh November. Ia bekerja sebagai dosen di Jurusan Teknik Industri Universitas Andalas sejak tahun 2000 sampai sekarang. Bidang penelitiannya adalah sistem rantai pasok dan riset operasi.

Milana, memperoleh gelar Sarjana Teknik dari Jurusan Teknik Industri, Universitas Andalas. Sedangkan gelar MSc dan PhD diperolehnya dari University of Bradford, UK. Ia bekerja sebagai dosen di Jurusan Teknik Otomotif Universitas Negeri Padang sejak 2008 sampai sekarang. Bidang penelitiannya adalah manajemen industri, knowledge management, dan KnowledgeBased/Expert System dalam lingkup optimasi sistem industri. 